\title{
Effects of Food Proteins on Sensory and Physico- Chemical Properties of Emulsified Pork Meatballs
}

\author{
C.K. Yeung, S.C. Huang* \\ Food Industry Research and Development Institute, Hsinchu, Taiwan, ROC \\ *Corresponding author: hsc30@firdi.org.tw
}

\begin{abstract}
Emulsified pork meatballs (Kung-Yuan or meatballs) are common emulsified meat products in Chinese cultures and are widely popular among Taiwanese and Chinese consumers. In recent years, the concept of clean labels has become prominent, and consumers have started to demand products without artificial additives. In this study, we investigated the effects of food proteins-soy protein, sodium caseinate, whey protein, egg albumen powder, and skim milk powder on the texture and sensory acceptability of phosphate-free meatballs. The results were compared with the texture and sensory acceptability of meatballs with phosphate. Texture analyses revealed that adding different food proteins to phosphate-free meatballs increased their hardness. Among them, meatballs with egg albumen powder were the hardest, followed by those with sodium caseinate and those with whey protein. Meatballs with phosphate and phosphate-free meatballs without any protein additive were less chewy than meatballs with any of the five protein additives, adding the egg albumen powder, sodium caseinate, and whey protein, however, could increase the meatballs' chewiness. Quality analyses showed that all groups of meatballs were had $\mathrm{pH}$ values between 6.36 and 6.96 and had water compositions between $49.81 \%$ and $56.79 \%$. Sensory evaluation revealed that soy protein had negative effects on sensory acceptance, whereas whey protein scored the highest in overall sensory evaluation. The composition analysis results of meatballs with whey protein and phosphate-free meatballs exhibited no significant differences. The hygiene quality test showed that the total plate count of all meatball groups were had less than $10^{5} \mathrm{CFU} / \mathrm{mL}$ and Escherichia coli and coliforms weren't detected. In summary, although adding soy protein negatively influenced the meatballs' sensory perceptions, all other types of food protein additives improved the texture of phosphate-free meatballs. The sensory evaluation indicated that adding whey protein is the most effective way to improve a meatball's texture. The sensory evaluation results indicated that the overall acceptance of meatballs with whey protein was not significantly different from that of meatballs with phosphate.
\end{abstract}

Keywords: meat products, meatballs, kung-wan, phosphate, protein

Cite This Article: C.K. Yeung, and S.C. Huang, "Effects of Food Proteins on Sensory and Physico-Chemical Properties of Emulsified Pork Meatballs." Journal of Food and Nutrition Research, vol. 6, no. 1 (2018): 8-12. doi: 10.12691/jfnr-6-1-2.

\section{Introduction}

Clean labels are a trend in the food industry and have captured consumers' attention. During the 1980s, the European Union introduced E numbers for food packaging. Food with fewer $\mathrm{E}$ numbers tended to be cleaner [1]. In recent years, increasingly, many studies have investigated clean labels [1], reflecting the interest in this topic. To date, Concept of clean label has not been clearly defined. In order to meet the requirements of sanitation, safety, and regulations and consider health, nutrition, sensory acceptance, and shelf life, manufacturers have tended to employ natural additives instead of artificial additives to increase consumer acceptance and willingness to purchase processed products.

Meatballs are common emulsified meat products in Chinese cultures. Compared with western meatballs, Chinese meatballs are springier [2] and are therefore favored by Taiwanese and Chinese consumers [3]. Meatballs are composed mainly of pork ham and back fat, and they contain additives such as phosphates, salt, and seasonings. Studies have demonstrated that approximately $14 \%$ of daily salt intake is derived from meat products [4,5]. Due to the rise of clean labels and consumers' increasing appeals for foods that are natural, healthy, less-processed, and low in additives, increasingly, many studies have investigated low-fat meatballs with few artificial additives $[3,6]$. For example, in some studies, the contents of artificial nitrates and phosphates in meatballs were reduced. The main roles phosphates play in meat products are to increase the extraction of salt-soluble proteins and enhance water retention $[7,8]$. Reduction of phosphates in meat products will reduce salt-soluble protein extraction and thus decrease the crosslinks between meats, leading to a decrease in the quality of the meat product. In response, studies have experimented with natural additives such as tapioca starch, carrageenan, whey protein, porcine blood plasma, and wheat bran to increase the quality of meat products $[9,10,11,12]$.

In this study, we investigated meatballs in which phosphates were substituted with food proteins, namely soy protein, 
sodium caseinate, whey protein, egg albumen powder, and skim milk powder, and investigated their effect on the texture and sensory acceptability of phosphate-free meatballs. The results were compared with the texture and sensory acceptability of meatballs with phosphate.

\section{Materials and Methods}

\subsection{Preparation of Meatballs (Kung-Yuan)}

The meatballs were manufactured according to a traditional formula for Taiwan-style meatballs (Kung-Yuan): 85\% Fresh pork ham (Cha I Shan Foods Co., Ltd, Taiwan) and $15 \%$ pork back fat (Cha I Shan Foods Co., Ltd, Taiwan) were mixed with $1.8 \%$ salt $(99.5 \%$, Taiyen Biotech Co., Ltd, Taiwan), 3.0\% sugar (99.5\%, Taiwan Sugar Co., Taiwan), $0.3 \%$ spices (Tomax Enterprise Co., Ltd, Taiwan), and $2 \%$ corn starch (LINCO Enterprise Co., Ltd, Taiwan). The tissues were ground with a meat chopper fitted with a plate of $20 \mathrm{~mm}$ diameter holes. The ground meat was packaged in plastic bags, $1.0 \mathrm{~kg}$ each, and stored at $-18^{\circ} \mathrm{C}$. Before use, the meats were maintained $20 \mathrm{~h}$ at $0^{\circ} \mathrm{C}$ and then they were mixed with the condiments and commercial whey protein(99.5\%, Yihyuan Co., Taiwan), skim milk powder, sodium caseinate (99.5\%, Gemfont Co., Taiwan), egg albumin (99.5\%, Gemfont Co., Taiwan) and isolated soy protein(99.5\%, Yihyuan Co., Taiwan). The sample was manufactured with sodium phosphate was considered as positive control and without sodium phosphate as negative control. As shown in Table 1, the experimental design consisted of two controls and five formulaes. After meatballs were boiled at $85^{\circ} \mathrm{C}$ until an internal temperature of $72^{\circ} \mathrm{C}$, they were cooled and packaged in plastic bags (NY/LLDPE laminated film). All sample( 0,400 , and $800 \mathrm{ppm})$ were measured at 3 day intervals and stored for up to 15 days at $4^{\circ} \mathrm{C}$ and on days 0 , 30 and 90 of storage at $-20^{\circ} \mathrm{C}$.

Table 1. The Abbreviation of Different Treatments

\begin{tabular}{|c|c|}
\hline Abbreviation & Treatment \\
\hline WP & Add 2\% whey protein \\
\hline SM & Add 4\% skim milk powder \\
\hline SC & Add 4\% sodium caseinate \\
\hline EA & Add 6\% egg albumin \\
\hline ISP & Add 6\% isolated soy protein \\
\hline PC & Add 0.3\% sodium phosphate \\
\hline NC & Without any food additives \\
\hline
\end{tabular}

\subsection{Texture Profile Analyses}

Frozen meatballs were placed in a cooler $\left(2^{\circ} \mathrm{C}\right)$ for approximately $12 \mathrm{~h}$. Once thawed, meatballs were heated at $100^{\circ} \mathrm{C}$ water bath for $7 \mathrm{~min}$ and then cooled to room temperature. For TPA measurement, the meatballs were cut by two sides to get a $20 \mathrm{~mm}$ depth strip. The texture profile analyses (TPA) indices of meatballs were determined using a texture analyzer (Model TA-XT2 Texture Analysis, England). The conditions of texture analyzer were modified by [13]. Pre-test speed: $2.0 \mathrm{~mm} / \mathrm{s}$; test speed: $2.0 \mathrm{~mm} / \mathrm{s}$; post-test speed: $2.0 \mathrm{~mm}$ / s; distance: $10.0 \mathrm{~mm}$; time: 5.0s; trigger type: auto; and trigger force, $10 \mathrm{~g}$.

\subsection{Physicochemical Properties of Meatballs}

The $\mathrm{pH}$ value of the meatballs was measured after homogenization (Interscience Co., Model BagMixer® 400P, France) with distilled water at a ration of 1:10 using a $\mathrm{pH}$ meter (Denver Instrument, USA). Moisture content was measured by the weight difference before and after oven drying at $105^{\circ} \mathrm{C}$ for $16 \mathrm{~h}$. Ash content was measured by AOAC, 1970 method [14]. Saturated fat and trans fat was measured by GC method [15]. Crude lipid content was measured by drying the sample in a $105^{\circ} \mathrm{C}$ oven for $6 \mathrm{~h}$ and then extracting the lipid with ether in a Soxhlet extractor for $4 \mathrm{~h}$. Crude protein content was measured by the Kjeldahl method (AOAC, 1984). The phosphate content measured by spectrophotometric ammonium molybdate method (AOAC, 1990) was based on using sulfuric acid to hydrolyze all phosphates into orthophosphates and measured at $690 \mathrm{~nm}$ with a spectrophotometer. Therefore, phosphate contents of the meatball samples were determined in terms of orthophosphates [7].

\subsection{Sensory Analysis}

The sensory analysis of meatballs was evaluated by 30 untrained assessors selected according to their habits. Samples were labeled with 3-digit random numbers and served in random order to assessor in individual booths. Assessors were instructed to cleanse their palates with water between samples. A hedonic test was carried out using 9 point scales ( 9 = like extremely and $1=$ dislike extremely) in which the assessors evaluated different attributes: appearance, taste, texture, flavor, overall acceptability [16].

\subsection{Microbial Status of Meatballs}

The total plate count of meatballs were determined using 3 M PetrifilmTM (3M Co., USA) Aerobic Count Plate (AOAC OMA: 990.12) [17]. Plates were incubated at $37^{\circ} \mathrm{C}$ for 48 hour. Results were expressed as $\log 10$ CFU/g meatballs.

Coliform and E. coli of meatballs were determined using 3 M PeterifilmTM (3M Co., USA) E. coli and Coliform Count Plate (AOAC OMA: 991.14) [18]. Plate were incubated at $37^{\circ} \mathrm{C}$ for 24 hour. Results were expressed as $\log 10 \mathrm{CFU} / \mathrm{g}$ meatballs.

\subsection{Statistical Analysis}

Data were analyzed using SPSS 12.0 for one-way ANOVA. Duncan's new multiple range test was used to resolve the difference among treatment means. A value of $p<0.05$ was used to indicate significant difference.

\section{Results and Discussion}

\subsection{The Texture Properties of Meatballs}

Texture analysis was an indicator for meatball quality. Table 2 shows the results from texture property analysis (TPA). The analysis of meatball hardness indicated that positive and negative control groups scored lower. Including different additives evidently increased the meatballs' hardness: the 6\% egg albumin (EA) treatment had the 
strongest effect, followed by the $4 \%$ sodium caseinate (SC) and $2 \%$ whey protein (WP) treatments. These results were similar to those of Hsu and Sun [3]. Adding egg albumen powder and sodium caseinate gave the meatballs a crispier texture, thereby increasing their hardness. The springiness and cohesiveness results were similar: the meatballs with the WP and 4\% skim milk powder (SM) treatments ranked higher in these two categories because of excellent hydration and gelatinization. Thus, whey protein could decrease the hardness in meatballs and increase their springiness [19,20]. Hsu and Sun [3] indicated that adding whey protein made meatballs stickier and that gumminess and chewiness displayed similar trends to that of hardness. In the gumminess and chewiness results, the $0.3 \%$ sodium phosphate (PC) and no food additives (NC) treatments ranked lower, whereas the EA, SC, and WP treatments increased meatballs' gumminess and chewiness. Therefore, the harder a meatball, the chewier it is. Texture analysis indicated that the PC and NC treatments yielded softer and less chewy meatballs. Additives can effectively improve a product's texture $[21,22]$ align it with consumers' preferences $[3,23]$. Thus, the PC and NC treatments created softer meatballs. Among the treatments, EA, SC, and WP improved meatballs' texture and yielded more favorable results by increasing meatballs' hardness and chewiness, thereby enhancing their acceptability to consumers.

\subsection{The Physical Characteristics of Meatballs}

Table 3 reveals that all the $\mathrm{pH}$ values for all groups were between approximately 6.36 and 6.96. The samples had water content between approximately $49.81 \%$ and 56.79\%. Atughone et al. [24] indicated that heat treatment increased the hydration and plasticizing capacity of nonmeat additives, resulting in an increased $\mathrm{pH}$ in uncooked meatballs. The meatballs with the PC and 6\% isolated soy protein (ISP) treatments had the highest $\mathrm{pH}$ values, possibly because phosphates have stronger hydration abilities [7,25], whereas soy protein has stronger water absorption properties [26], resulting in meatballs with higher water content. The meatballs with PC and SC treatments contained the highest ash content, followed by those with the SM treatment. The PC and SC treated meatballs contained sodium, whereas SM treated ones were less purified and contained more minerals. Therefore, meatballs with PC, SC, and SM treatments contained higher ash content, whereas meatballs with other treatments exhibited no significant differences. Phosphate was only detected in meatballs with PC treatment. Because the treatments of the other groups did not involve phosphate, phosphate was not detected in those meatballs.

\subsection{The Microbial Status of Meatballs}

Figure 1 illustrates meatball hygiene under different treatments. The results showed that $E$. coli and coliforms were not found in any meatballs. The Total Viable Count (TVC) in each group was less than 105, although some groups contained more bacteria than others. The TVCs of the meatballs with the WP and ISP treatments were lower than that of the positive control group. The TVC of the meatballs with EA treatment was the lowest, whereas those of the meatballs with SC and SM treatments were slightly higher than that of the positive control group.

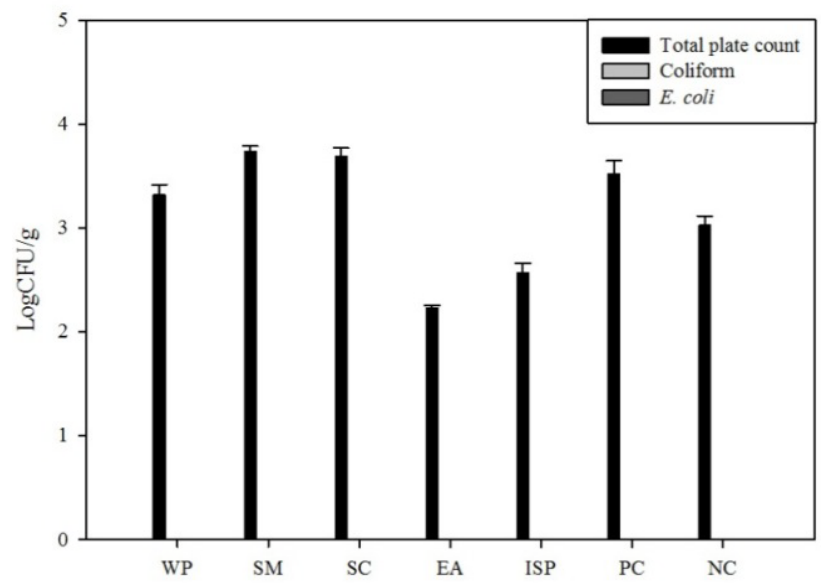

Figure 1. The Microbial Status of Meatballs Added Different Kinds of Food Proteins

Table 2. The Texture Properties (TPA) of Meatballs Added Different Kinds of Food Proteins $($ Mean \pm SD, $n=15)$

\begin{tabular}{|c|c|c|c|c|c|}
\hline Treatment & Hardness (g) & Springiness & Cohesiveness & Gumminess (g) & Chewiness (g) \\
\hline WP & $1578 \pm 239^{c}$ & $0.92 \pm 0.01^{\mathrm{ab}}$ & $0.76 \pm 0.01^{\mathrm{a}}$ & $1208 \pm 177^{\mathrm{bc}}$ & $1105 \pm 145^{\mathrm{bc}}$ \\
\hline SM & $1479 \pm 194^{\text {cd }}$ & $0.92 \pm 0.01^{\mathrm{bc}}$ & $0.75 \pm 0.02^{b}$ & $1152 \pm 180^{\text {cd }}$ & $1058 \pm 169^{\text {cd }}$ \\
\hline SC & $1829 \pm 304^{b}$ & $0.90 \pm 0.01^{\mathrm{d}}$ & $0.73 \pm 0.02^{\mathrm{c}}$ & $1312 \pm 193^{b}$ & $1180 \pm 159^{b}$ \\
\hline EA & $2374 \pm 307^{\mathrm{a}}$ & $0.93 \pm 0.01^{\mathrm{a}}$ & $0.77 \pm 0.01^{\mathrm{a}}$ & $1806 \pm 209^{\mathrm{a}}$ & $1670 \pm 186^{\mathrm{a}}$ \\
\hline ISP & $1626 \pm 137^{\mathrm{C}}$ & $0.90 \pm 0.01^{\mathrm{d}}$ & $0.71 \pm 0.02^{\mathrm{d}}$ & $1153 \pm 117^{\text {cd }}$ & $1037 \pm 109^{\text {cd }}$ \\
\hline $\mathrm{PC}$ & $1379 \pm 183^{d}$ & $0.91 \pm 0.02^{c}$ & $0.76 \pm 0.03^{\mathrm{a}}$ & $1052 \pm 137^{\mathrm{d}}$ & $958 \pm 130^{\mathrm{d}}$ \\
\hline $\mathrm{NC}$ & $1505 \pm 117^{\mathrm{cd}}$ & $0.92 \pm 0.01^{\mathrm{abc}}$ & $0.75 \pm 0.01^{\mathrm{b}}$ & $1128 \pm 80^{\mathrm{cd}}$ & $1034 \pm 76^{\text {cd }}$ \\
\hline
\end{tabular}

Means with different superscript letters within the same column are significantly different at $p<0.05$.

Table 3. The Physical Characteristics of Meatballs Added Different Kinds of Food Proteins $($ Mean \pm SD, $n=3)$

\begin{tabular}{|c|c|c|c|c|}
\hline Treatment & $\mathrm{pH}$ value & Water Content (\%) & Ash (\%) & Phosphate (\%) \\
\hline WP & $6.56 \pm 0.01^{b}$ & $53.73 \pm 0.01^{\mathrm{b}}$ & $0.88 \pm 0.01^{\mathrm{c}}$ & N.D. \\
\hline SM & $6.53 \pm 0.01^{b}$ & $50.99 \pm 0.01^{\mathrm{c}}$ & $0.96 \pm 0.01^{b}$ & N.D. \\
\hline SC & $6.96 \pm 0.01^{\mathrm{a}}$ & $51.68 \pm 0.01^{\mathrm{c}}$ & $1.13 \pm 0.01^{\mathrm{a}}$ & N.D. \\
\hline EA & $6.49 \pm 0.01^{b}$ & $49.81 \pm 0.01^{\mathrm{c}}$ & $0.88 \pm 0.01^{\mathrm{c}}$ & N.D. \\
\hline ISP & $6.85 \pm 0.01^{\mathrm{a}}$ & $55.15 \pm 0.01^{\mathrm{a}}$ & $0.91 \pm 0.01^{\mathrm{c}}$ & N.D. \\
\hline $\mathrm{PC}$ & $6.58 \pm 0.01^{b}$ & $56.79 \pm 0.01^{\mathrm{a}}$ & $1.35 \pm 0.01^{\mathrm{a}}$ & $0.18 \pm 0.01$ \\
\hline $\mathrm{NC}$ & $6.36 \pm 0.01^{b}$ & $52.97 \pm 0.01^{b}$ & $0.87 \pm 0.01^{\mathrm{c}}$ & N.D. \\
\hline
\end{tabular}

N.D. means not detected.

Means with different superscript letters within the same column are significantly different at $\mathrm{p}<0.05$. 
Table 4. The Sensory Evaluation of Meatballs Added Different Kinds of Food Proteins (Mean \pm SD, $n=30)$

\begin{tabular}{|c|c|c|c|c|c|}
\hline Treatment & Appearance & Taste & Flavour & Texture & Overall \\
\hline WP & $6.5 \pm 1.2^{\mathrm{a}}$ & $7.0 \pm 1.2^{\mathrm{a}}$ & $6.9 \pm 1.3^{\mathrm{a}}$ & $7.0 \pm 1.3^{\mathrm{a}}$ & $7.2 \pm 1.2^{\mathrm{a}}$ \\
\hline SM & $6.1 \pm 1.5^{\mathrm{a}}$ & $6.4 \pm 1.4^{\mathrm{ab}}$ & $6.4 \pm 1.4^{\mathrm{ab}}$ & $6.5 \pm 1.4^{\mathrm{ab}}$ & $6.4 \pm 1.5^{\mathrm{bc}}$ \\
\hline SC & $6.5 \pm 1.3^{\mathrm{a}}$ & $6.5 \pm 1.1^{\mathrm{ab}}$ & $6.4 \pm 1.2^{\mathrm{ab}}$ & $6.5 \pm 1.3^{\mathrm{ab}}$ & $6.4 \pm 1.2^{\mathrm{bc}}$ \\
\hline EA & $6.4 \pm 1.1^{\mathrm{a}}$ & $5.1 \pm 1.7^{\mathrm{c}}$ & $4.7 \pm 1.7^{\mathrm{C}}$ & $5.9 \pm 1.5^{b}$ & $4.8 \pm 1.9^{\mathrm{d}}$ \\
\hline ISP & $4.8 \pm 1.6^{b}$ & $4.7 \pm 1.6^{\mathrm{c}}$ & $4.6 \pm 1.7^{\mathrm{c}}$ & $3.3 \pm 1.5^{\mathrm{c}}$ & $3.5 \pm 1.6^{\mathrm{e}}$ \\
\hline $\mathrm{PC}$ & $6.5 \pm 0.6^{\mathrm{a}}$ & $6.7 \pm 0.7^{\mathrm{a}}$ & $6.8 \pm 1.4^{\mathrm{ab}}$ & $6.7 \pm 1.4^{\mathrm{a}}$ & $6.9 \pm 1.3^{\text {ab }}$ \\
\hline $\mathrm{NC}$ & $6.1 \pm 0.7^{\mathrm{a}}$ & $6.0 \pm 0.6^{b}$ & $6.1 \pm 1.4^{b}$ & $5.8 \pm 1.5^{b}$ & $5.8 \pm 1.5^{c}$ \\
\hline
\end{tabular}

Means with different superscript letters within the same column are significantly different at $\mathrm{p}<0.05$.

Table 5. The Proximate Composition of Meatballs Added Different Kinds of Food Proteins $(\mathrm{Mean} \pm \mathrm{SD}, \mathbf{n}=3)$

\begin{tabular}{|c|c|c|c|c|c|c|c|}
\hline Treatment & Water Content (\%) & Protein (\%) & Fat (\%) & Saturated Fat (\%) & Trans Fat (\%) & Ash (\%) & Carbohydrate (\%) \\
\hline WP & $53.73 \pm 0.01^{\mathrm{a}}$ & $16.04 \pm 0.01^{\mathrm{a}}$ & $29.48 \pm 0.01^{\mathrm{a}}$ & $10.33 \pm 0.01^{\mathrm{a}}$ & $0.07 \pm 0.01^{\mathrm{a}}$ & $0.88 \pm 0.01^{a}$ & 0.75 \\
\hline NC & $52.97 \pm 0.01^{\mathrm{a}}$ & $15.74 \pm 0.00^{\mathrm{a}}$ & $29.79 \pm 0.01^{\mathrm{a}}$ & $10.46 \pm 0.01^{\mathrm{a}}$ & $0.06 \pm 0.01^{\mathrm{a}}$ & $0.87 \pm 0.01^{\mathrm{a}}$ & 0.63 \\
\hline
\end{tabular}

Means with different superscript letters within the same column are significantly different at $\mathrm{p}<0.05$.

\subsection{The Sensory Evaluation of Meatballs}

The sensory evaluation reflected consumers' degrees of satisfaction. Meatballs with the ISP treatment ranked lower in appearance, but other groups exhibited no significant differences in their appearances (Table 4). Additives did not reduce consumers' favor for meatballs; in fact, they made meatballs more favorable than those with PC treatment. Meatballs with ISP treatment received the lowest score in the sensory evaluation, which was even lower than that of the negative control group, possibly because the soy protein notably altered meatballs' flavor, despite improving their texture. Consequently, consumers found them less acceptable $[3,27]$. Lee et al. [26] indicated that adding $<1 \%$ of soy protein mitigated impairments to the flavor, texture, color, and overall acceptability of emulsified sausages. Although meatballs with the EA treatment scored highly in the TPA results, their acceptance among consumers was not correspondingly positive, possibly because the EA treatment increased the meatballs' hardness and chewiness. However, Hsu and Chung [2] noted that, although harder meatballs were more favored by consumers, excessive hardness decreased meatballs' overall acceptance [28]. Consequently, the meatballs with the EA treatment scored poorly in the sensory evaluation. Meatballs with the WP treatment had the most favorable results, which were even superior to those of the PC treatment. Therefore, the WP treatment would not affect meatballs' texture, and WP treated meatballs are suitable for consumers' preferences.

\subsection{The Proximate Composition of Meatballs Added Within Whey Protein}

The sensory evaluation results revealed that meatballs with the WP treatment had similar or higher consumer acceptance compared with meatballs treated with PC. To investigate whether those two meatballs groups differed in their basic compositions, we analyzed their proximate compositions and found no significant differences (Table 5). Bishop [29] mentioned that water-to-protein ratio affects meatballs' juiciness and tenderness. The higher this ratio is, the juicier and more tender the meatballs are. In the present study, meatballs with the WP and NC treatments contained similar water-to-protein ratios. Therefore, applying the WP treatment to meatballs does not decrease their juiciness or tenderness. In fact, these meatballs scored even higher in consumers' sensory evaluation. Hsu and Sun [3] specified that adding additives at $<4 \%$ does not significantly affect the crude protein content in meat products. Therefore, the addition of $2 \%$ whey protein in this study did not substantially affect the basic composition of the meatballs.

\section{References}

[1] Asioli, D., Aschemann-Witzel, J., Caputo, V., Vecchio, R., Annunziata, A., Næs, T. and Varela, P, "Making sense of the "clean label" trends: A review of consumer food choice behavior and discussion of industry implications," Food Research International, 99. 58-71. 2017.

[2] Hsu, S. Y. and Chung, H. Y., "Effects of processing factors on qualities of emulsified meatball, " Journal of Food Engineering, 36(3). 337-347. 1998

[3] Hsu, S. Y. and Sun, L. Y., "Comparisons on 10 non-meat protein fat substitutes for low-fat Kung-wans," Journal of Food Engineering, 74(1). 47-53. 2006.

[4] Safefood, "How much salt are you eating, "2012. Available: http://www.safefood.eu/Consumer/Healthy-Living/EatingWell/Shake-the-salt-habit/How-much-salt-areyou-eating-.aspx. [accessed 18/09/2017]

[5] O'Flynn, C. C., Cruz-Romero, M. C., Troy, D., Mullen, A. M. and Kerry, J. P., "The application of high-pressure treatment in the reduction of salt levels in reduced-phosphate breakfast sausages, " Meat science, 96(3). 1266-1274. 2014.

[6] Kuraishi, C., Sakamoto, J., Yamazaki, K., Susa, Y., Kuhara, C. and Soeda, T., "Production of restructured meat using microbial transglutaminase without salt or cooking, " Journal of Food Science, 62(3). 488-490. 1997.

[7] Ünal, S. B., Erdoğdu, F. and Ekiz, H. İ., "Effect of temperature on phosphate diffusion in meats," Journal of food engineering, Volume, 76(2), 119-127, 2006.

[8] Xiong, Y. L., Ho, C. T. and Shahidi, F., Quality characteristics of muscle foods, Quality Attributes of Muscle Foods, 1-10. 1999.

[9] Ruusunen, M., Vainionpää, J., Puolanne, E., Lyly, M., Lähteenmäki, L., Niemistö, M. and Ahvenainen, R., "Physical and sensory properties of low-salt phosphate-free frankfurters composed with various ingredients," Meat Science, 63(1). 9-16. 2003.

[10] Hurtado, S., Saguer, E., Toldrà, M., Parés, D. and Carretero, C., "Porcine plasma as polyphosphate and caseinate replacer in frankfurters," Meat science, 90(3). 624-628, 2012.

[11] Zouari, N., Ayadi, M. A., Hadj-Taieb, S., Frikha, F. and Attia, H., "Whey powder, 1-carrageenan, and fat interactions and their influence on instrumental texture and sensory properties of turkey meat sausage using a mixture design approach," International journal of food properties, 15(6).1233-1246, 2012.

[12] Tekin, H., Saricoban, C. and Yilmaz, M. T., "Fat, wheat bran and salt effects on cooking properties of meat patties studied by 
response surface methodology," International journal of food science \& technology, 45(10). 1980-1992. 2010.

[13] Huang S.C., Shiau, C. Y., Liu, T.E., Chu, C. L. and Hwang, D.F. "Effects of rice bran on sensory and physico-chemical properties of emulsified pork meatballs," Meat Science, 70. 613-619. 2005

[14] Perez, D. and Andujar, G., "Determination of ash content in meat products." Meat science, 5(3). 165-170. 1981.

[15] Salimon, J., Omar, T. A. and Salih, N., "An accurate and reliable method for identification and quantification of fatty acids and trans fatty acids in food fats samples using gas chromatography," Arabian Journal of Chemistry, 10. S1875-S1882. 2017.

[16] Meilgaard, M., Civille G.V. and Carr. B.T, Sensory evaluation techniques, 2nd Ed, CRC Press, USA, 1991.

[17] AOAC, AOAC Official Method 990.12 for Aerobic Plate Count in Foods, Official methods of analysis, $14^{\text {th }}$ Ed, DC: Association of Official Analytical Chemists, Wshington, DC., 1995.

[18] AOAC, AOAC Official Method 991.14 for Coliform and Escherichia coli Counts in Foods, Official methods of analysis, $14^{\text {th }}$ Ed, DC: Association of Official Analytical Chemists, Washington, DC., 1995.

[19] Brewer, M. S., "Reducing the fat content in ground beef without sacrificing quality: A review," Meat Science, 91. 385-395. 2012.

[20] Youssef, M. K. and Barbut, S., "Effects of caseinate, whey and milk proteins on emulsified beef meat batters prepared with different protein levels," Journal of muscle foods, 21(4). 785-800. 2010.

[21] Pietrasik, Z., Jarmoluk, A. and Shand, P. J., "Effect of non-meat proteins on hydration and textural properties of pork meat gels enhanced with microbial transglutaminase," LWT-Food Science and Technology, 40(5). 915-920. 2007.
[22] Fernández-Martın, F., Cofrades, S., Carballo, J. and JiménezColmenero, F., "Salt and phosphate effects on the gelling process of pressure/heat treated pork batters," Meat Science, 61(1). 15-23. 2002.

[23] Serdaroglu, M. and Ozsumer, M. S., "Effects of soy protein, whey powder and wheat gluten on quality characteristics of cooked beef sausages formulated with 5, 10 and 20\% fat," Food Science and Technology, 6(2). 2003.

[24] Atughonu, A. G., Zayas, J. F., Herald, T. J. and Harbers, L. H., "Thermo-Rheology, Quality Characteristics, And Microstructure Of Frankfurters Prepared With Selected Plant And Milk Additives," Journal of Food Quality, 21(3). 223-238. 1998.

[25] Xiong, Y. L., Ho, C. T. and Shahidi, F., "Quality characteristics of muscle foods," Quality attributes of muscle foods, 1-10. 1999.

[26] Lee, C. W., Kim, T. K., Hwang, K. E., Kim, H. W., Kim, Y. B., Kim, C. J. and Cho, Y. S., "Combined Effects of Wheat Sprout and Isolated Soy Protein on Quality Properties of Breakfast Sausage, " Korean journal for food science of animal resources, Volume 37(1), 52, 2017.

[27] Homco-Ryan, C. L., Ryan, K. J., Wicklund, S. E., Nicolalde, C. L., Lin, S., McKeith, F. K. and Brewer, M. S., "Effects of modified corn gluten meal on quality characteristics of a model emulsified meat product." Meat science, 67(2). 335-341. 2004.

[28] Hsu, S. Y. and Yu, S. H., "Comparisons on 11 plant oil fat substitutes for low-fat kung-wans," Journal of food Engineering, 51(3). 215-220. 2002.

[29] Bishop, D. J., Olson, D. G. and Knipe, C. L., "Pre-Emulsified Corn Oil, Pork Fat, or Added Moisture Affect Quality of Reduced Fat Bologna Quality," Journal of Food Science, 58(3). 484-487. 1993. 